\title{
Awareness and Willingness to Pay for Health Insurance: A Study on Selected Government and Non-Government Employees of Bangladesh
}

\author{
Mohsin $\mathrm{M}^{1}$, Islam $\mathrm{MZ}^{2}$, Ahmed $\mathrm{MU}^{3}$ \\ DOl:https://doi.org/10.3329/jafmc.v16i2.55289
}

\begin{abstract}
Introduction: The high cost of health services along with the unpredictability of health needs and the inadequacy of personal savings is the primary reason for the growing importance of insurance as a means of financing health services. Health insurance ensures easy access, high quality, sustainability and affordability of care. This study was undertaken in an attempt to generate some scientific data on awareness and willingness to pay (WTP) for health insurance in our country perspective.
\end{abstract}

Objective: To determine awareness and demand or willingnessto-pay for health insurance in order to ascertain the feasibility of such schemes and establishing prices.

Materials and Methods: This descriptive cross-sectional study was carried out from 1st July 2015 to 30th June 2016 in two government and two non-government organizations. Randomly 200 government and 200 non-government employees were taken in the sample. A semi structured questionnaire designed to elicit WTP by Contingent Valuation Method (CVM) was used to collect data.

Results: Among 400 respondents, $82.8 \%$ were male and $17.2 \%$ were female. Most of them (85.5\%) heard about health insurance earlier and 2.5\% subscribed for health insurance. Majority (58.7\%) expressed WTP Tk 100-200 (Mean Tk $261.3 \pm 196.3$ ) and by percentage of monthly income, average WTP of a formal sector employee was $1.2 \%$. Coverage of health expenditure from employer (10.6\%) or insurance (1.1\%) side was less and $88.8 \%$ of employees had to spend $100 \%$ from out of pocket (OOP).

Conclusion: Introduction of health insurance, appropriately designed for each population group is imperative for achieving Universal Health Coverage.

Key-words: Willingness to pay, Awareness, Health insurance, Formal sector employees.

\section{Introduction}

Access to affordable and quality health care is a major problem in many countries like Bangladesh. Technological advancements in the health sector, along with the emergence and re-emergence of diseases caused escalation of health care costs tremendously.
Health insurance is important because health status is associated with uncertainty and risk. When a serious illness or an accident occurs, health insurance can cover some of the financial losses as well as can ease the access to health care. It is a sophisticated risk management strategy, which can protect individuals or households from severe financial crisis generated by idiosyncratic shocks ${ }^{1}$. Along with high cost and unpredictability of health need, people usually suffer from inadequacy of personal savings while paying for health services. Health financing in many low and middle income countries (LMICs) is characterized by high levels of out-of-pocket (OOP) expenditure for serious illnesses leading to potentially catastrophic payment for health care among its citizens ${ }^{2}$. Catastrophic health expenditure is a situation where a household spends on health more than $40 \%$ of its income after paying for subsistence needs, i.e. food ${ }^{3}$.

Over last two decades Bangladesh achieved a lot in the field of public health, in terms of improvement in health indicators and attainment of most of the health related global targets such as Sustainable Development Goals. But still this country is lacking behind many fast growing countries like China, Malaysia, Vietnam, or Thailand in Universal Health Coverage. Health insurance is considered by WHO as a key route to Universal Health Coverage. Less than $1 \%$ population, mainly from formal sector has got some sort of social health protection coverage in Bangladesh ${ }^{3}$. Again, the limited health care coverage enjoyed by formal sector of Bangladesh seems grossly inadequate in terms of quality and financial risk protection. Since its inception in seventeenth century the concept of health Insurance evolved into modern health insurance schemes in 20th century. The first social health insurance fund was established in Germany in 1883. Over time, systems have developed to guarantee access to health care, to provide high quality and appropriate care and also to maintain the sustainability and affordability of care ${ }^{4}$.

Health insurance is more complex than other forms of insurance because of its social security or safety net component, coverage levels, cost containment and technicality of quality as well as access control issues. It requires epidemiological, institutional and technical considerations along with complex demand and supply side analysis. In Bangladesh some private insurance companies offer limited health insurance coverage. Private health insurance accounts for an insignificant share $(0.2 \%)$ in total health

1. Col Mohammad Mohsin, MBBS, MPH, MPhil, Contingent Commander, Level 2 Hospital (UNPCRS), Rajendrapur Cantonment (E-mail: mmohsin736@gmail.com) 2. Professor Md Ziaul Islam, MBBS, MPH, PGD, MSc, PhD, Head of the Department of Community Medicine, National Institute of Preventive and Social Medicine, Mohakhali, Dhaka 3. Brig Gen Mohsen Uddin Ahmed, MBBS, MPH, MHI, Deputy Commandant, Armed Forces Medical College, Dhaka. 
expenditure ${ }^{3}$. Bangladesh is actively seeking to achieve Universal Health Coverage (UHC) through mandatory social health insurance (SHI) with a social safety net for below poverty line poor under social health protection scheme. Already a 20 years action plan is undertaken so that universal coverage can be attained by 2032 through extending financial risk protection and ensuring access to quality service ${ }^{3}$.

Public spending accounts for $26 \%$ of total health expenditure in Bangladesh and rest $74 \%$ is private spending, out of which $64 \%$ comes from 'out of pocket' (OOP) ${ }^{3}$. Formal sector represents $12.3 \%$ of total population of Bangladesh. It is 18.8 million people out of 152.5 million total population of Bangladesh, as per 2012 estimate $^{3}$. But economic unit wise, formal sector represents $56.2 \%$ of all economic units of Bangladesh ${ }^{5}$. As part of the broader perspective, policymakers need to concentrate on government employees first by immediately introducing mandatory social health insurance for them. The private formal sector may be included in the next phase of the scheme. In some of the countries that have attained universal coverage through social health protection schemes, the process started with the formal sector first. Low and middle income countries are suggested to start introducing social health insurance in the formal sector where income levels are higher ${ }^{6}$.

The willingness to pay (WTP) is the highest price an individual is willing to accept to pay for some good or service. Many health economists believe that eliciting willingness to pay for health insurance is needed for the development of health insurance ${ }^{7,8}$. WTP estimates can be derived using different methods and the elicitation of WTP in a contingent valuation survey to value health outcomes, has increased significantly ${ }^{9}$. Contingent valuation method (CVM) aims to obtain information on individual preferences by asking direct questions about willingness to pay for public good and services when prices are not available ${ }^{10}$.This study was conducted to determine willingness to pay (WTP) for a social health insurance scheme among government and non-government sector employees of Bangladesh using contingent valuation method (CVM).

\section{Materials and Methods}

This descriptive cross-sectional study was carried out from 1st July 2015 to 30th June 2016 with the aim to determine willingness to pay (WTP) for health insurance, to assess awareness about health insurance and to find out preferences related to WTP for health insurance among formal sector employees. Two government organizations and two non-government corporate organizations were selected purposively in and around Dhaka city. All the employees working in the selected organizations during data collection period were study population. A total of 400 respondents (200 government employees and 200 non-government employees) were selected by simple random sampling. Sample size was determined by $n=Z^{\wedge} 2 \mathrm{pq} / \mathrm{d}^{\wedge} 2$ formula and it came 358 but raised to 400 considering chances of some non-response. A pre-tested semi structured questionnaire was used as data collection instrument. Part of the questionnaire was designed to elicit WTP for a hypothetical health insurance package by Contingent Valuation Method (CVM) using "unidirectional bidding game" technique. Bidding ranged from 100 Taka to 600 Taka with a provision for a highest bid. Respondents were invited to determine their WTP in Taka by reference to lowest opening bid; if the respondent accepted the amount the bid was raised by 50 Taka each time, until the respondent declined the amount. The highest accepted bid was recorded as the WTP level. Data were collected through face to face interview. Data obtained were entered into SPSS-21 version. The univariate and bivariate analysis were carried out. Keeping compliance with Helsinki Declaration for Medical Research Involving Human Subjects 1964, the participants were informed verbally about the study design, the purpose of the study and informed written consent was obtained. They were assured of protection of self-autonomy, privacy and confidentiality.

\section{Results}

Among 400 respondents, $82.8 \%$ were male and $17.2 \%$ were female. All the employees interviewed were within the age range of 20 to 59 years (Mean 35 \pm 9.3 years). Among all respondents, $65 \%$ were main earners in their families. Length of service ranged from 1 to 35 years (Mean $9.4 \pm 5.7$ years). Range of monthly income of respondents was from Tk 5000 to Tk 100000 (Mean Tk. $21089.1 \pm$ 17525.7). Their family size ranged from 2 to 12 members (Mean 5.0 \pm 2.0 members). Table-I shows that total $85.5 \%$ respondents $(83 \%+2.5 \%)$ heard about health insurance earlier and among them $2.5 \%$ subscribed for some form of health insurance. It also shows that, more non-government employees (1.7\%) subscribed for health insurance than government employees $(0.8 \%)$. Total ready to join health insurance scheme either unconditionally or on condition of government or employer contribution was $83 \%$ $(40.5 \%+42.5 \%)$ of respondents. Rest $17 \%(9 \%+8 \%)$ were actually not ready to join. Maximum (58.7\%) were willing to pay Tk. 100-200 per month, followed by $20.2 \%$ respondents Tk. $250-350$ per month. Overall mean WTP was Tk $261.3 \pm 196.3$ and on comparison it was found lower (Tk. $241.2 \pm 196.5$ ) in case of government employees than that of non-government employees (Tk. $282.4 \pm 194.5$ ).

Table-Il shows average WTP as percentage of monthly income of respondents. It was found overall $1.2 \%$ of monthly income and in government employees it was found higher $(1.7 \%)$ than that of non-government employees (1.0\%). Figure-1 shows majority $67.8 \%$ respondents preferred monthly premium payment, followed by $15.4 \%$ quarterly, $9.0 \%$ half yearly and $7.8 \%$ yearly. Table-III shows that total $73.7 \%$ of respondents or their family members suffered from at least one episode of illness. Among those who suffered from illness, $70.7 \%$ seek treatment. Table-IV shows that all of the respondents who seek treatment had to spend from their own pocket. Only $1.1 \%$ got health insurance coverage, $4.2 \%$ government employees got partial coverage from government and

\section{(10)}


$18(6.4 \%)$ non-government employees got partial coverage from their employer. Figure-2 shows that those who had to spend on health care, majority $(43.1 \%+45.7 \%) 88.8 \%$ incurred $100 \%$ of their health care expenditure out of pocket (OOP).

Table-I: Distribution of respondents by awareness, willingness to join the scheme and Willingness to Pay for health insurance $(n=400)$

\begin{tabular}{|l|l|r|r|r|}
\hline \multicolumn{2}{|c|}{ Variables } & \multicolumn{2}{|c|}{ Type of employee } & \multirow{2}{*}{$\begin{array}{l}\text { Total } \\
\text { n (\%) }\end{array}$} \\
\cline { 3 - 4 } & $\begin{array}{l}\text { Government } \\
\mathrm{n}(\%)\end{array}$ & $\begin{array}{c}\text { Non-government } \\
\mathrm{n}(\%)\end{array}$ & \\
\hline \multirow{5}{*}{ Awareness } & $\begin{array}{l}\text { Heard about health } \\
\text { insurance and } \\
\text { subscribed }\end{array}$ & $3(0.8)$ & $7(1.7)$ & $10(2.5)$ \\
\cline { 2 - 4 } & $\begin{array}{l}\text { Heard about health } \\
\text { insurance but did not } \\
\text { subscribe }\end{array}$ & $169(42.2)$ & $163(40.8)$ & $332(83.0)$ \\
\cline { 2 - 4 } & $\begin{array}{l}\text { Never heard about } \\
\text { health insurance }\end{array}$ & $28(7.0)$ & $30(7.5)$ & $58(14.5)$ \\
\hline \multirow{4}{*}{$\begin{array}{l}\text { Willingness } \\
\text { to join }\end{array}$} & Not ready to join & $16(4.0)$ & $20(5.0)$ & $36(9.0)$ \\
\cline { 2 - 4 } & Still need some time & $14(3.5)$ & $18(4.5)$ & $32(8.0)$ \\
\cline { 2 - 4 } & Ready to join & $82(20.5)$ & $80(20.0)$ & $162(40.5)$ \\
\cline { 2 - 4 } & $\begin{array}{l}\text { Ready to join if } \\
\text { govemment employer } \\
\text { makes contribution }\end{array}$ & $88(22.0)$ & $82(20.5)$ & $170(42.5)$ \\
\hline \multirow{3}{*}{$\begin{array}{l}\text { Willingness } \\
\text { to Pay for } \\
\text { health } \\
\text { insurance } \\
\text { (Taka) }\end{array}$} & $100-200$ & $114(34.3 \%)$ & $81(24.4 \%)$ & $195(58.7 \%)$ \\
\cline { 2 - 4 } & $250-350$ & $25(7.5 \%)$ & $42(12.7 \%)$ & $67(20.2 \%)$ \\
\cline { 2 - 4 } & $400-500$ & $21(6.4 \%)$ & $29(8.7 \%)$ & $50(15.1 \%)$ \\
\cline { 2 - 4 } & $\geq 550$ & $10(3.0 \%)$ & $10(3.0 \%)$ & $20(6.0 \%)$ \\
\cline { 2 - 4 } & Mean \pm SD & $241.2 \pm 196.5$ & $282.4 \pm 194.5$ & $261.3 \pm 196.3$ \\
\hline
\end{tabular}

Table-II: Distribution of mean WTP and WTP as percentage of monthly income by types of employees $(n=332)$

\begin{tabular}{|l|c|c|c|}
\hline $\begin{array}{c}\text { Type of job } \\
\text { (a) }\end{array}$ & $\begin{array}{c}\text { Mean monthly } \\
\text { income (Tk) } \\
\text { (b) }\end{array}$ & $\begin{array}{c}\text { Mean } \\
\text { Willingness to } \\
\text { pay (Tk) } \\
\text { (c) }\end{array}$ & $\begin{array}{c}\text { WTP as } \\
\text { percentage of } \\
\text { income (\%) } \\
d \quad \begin{array}{c}\text { ( }) \\
-100\end{array}\end{array}$ \\
\hline Government & 14459.8 & 241.2 & 1.7 \\
\hline $\begin{array}{l}\text { Non- } \\
\text { government }\end{array}$ & 27718.5 & 282.4 & 1.0 \\
\hline Overall & 21089.1 & 261.3 & 1.2 \\
\hline
\end{tabular}

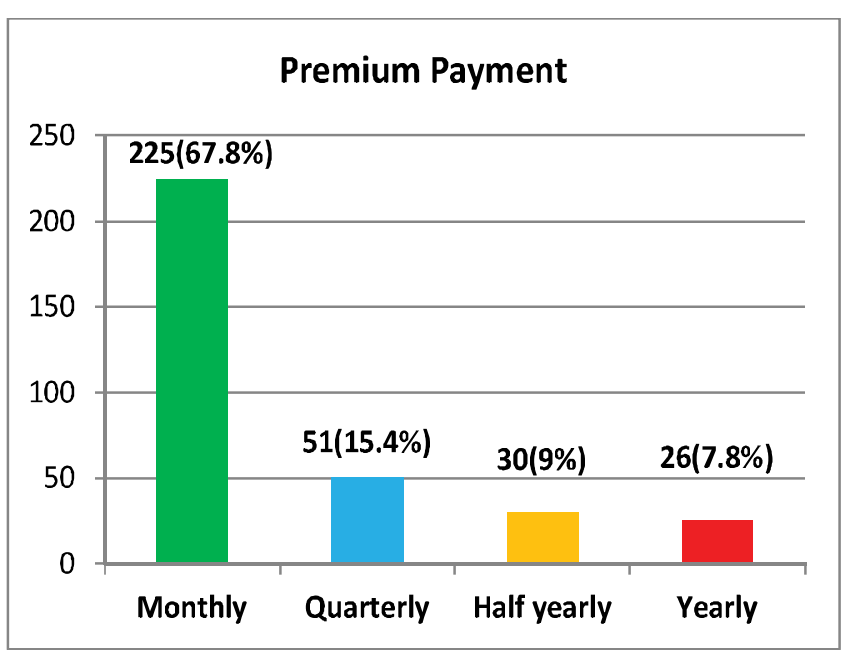

Figure-1: Distribution of respondents by preference for mode of premium payment $(\mathrm{n}=332)$
Table-IIl: Distribution of respondents by illness of family members during last three months $(n=400)$

\begin{tabular}{|l|c|c|c|}
\hline \multirow{2}{*}{$\begin{array}{l}\text { Illness of family } \\
\text { members }\end{array}$} & \multicolumn{2}{|c|}{ Treatment seeking } & \multirow{2}{*}{ Total } \\
\cline { 2 - 3 } & Yes & No & \\
\hline $\begin{array}{l}\text { Acute or } \\
\text { chronic illness } \\
\text { during last 3 } \\
\text { months }\end{array}$ & $\begin{array}{c}283 \\
(70.7 \%)\end{array}$ & $12(3 \%)$ & $295(73.7 \%)$ \\
\hline $\begin{array}{l}\text { No illness } \\
\text { during last 3 } \\
\text { months }\end{array}$ & - & $\begin{array}{c}105 \\
(26.3 \%)\end{array}$ & $105(26.3 \%)$ \\
\hline Total & $\begin{array}{c}\mathbf{2 8 3} \\
\mathbf{( 7 0 . 7 \% )}\end{array}$ & $\begin{array}{c}\mathbf{1 1 7} \\
\mathbf{( 2 9 . 3 \% )}\end{array}$ & $\mathbf{4 0 0 ( \mathbf { 1 0 0 . 0 \% ) }}$ \\
\hline
\end{tabular}

Table-IV: Distribution of respondents by sources of health care expenditure coverage $(n=283)$

\begin{tabular}{|l|c|c|c|}
\hline \multirow{2}{*}{$\begin{array}{l}\text { Health care cost } \\
\text { covered by }\end{array}$} & \multicolumn{2}{|c|}{ Type of employee } & \multirow{2}{*}{ Total } \\
\cline { 2 - 3 } & Government & $\begin{array}{c}\text { Non- } \\
\text { Government }\end{array}$ & \\
\hline Own & $134(47.3 \%)$ & $149(52.7 \%)$ & $283(100.0 \%)$ \\
\hline $\begin{array}{l}\text { Government/ } \\
\text { Employer }\end{array}$ & $12(4.2 \%)$ & $18(6.4 \%)$ & $30(10.6 \%)$ \\
\hline $\begin{array}{l}\text { Insurance } \\
\text { company }\end{array}$ & $0(0.0 \%)$ & $3(1.1 \%)$ & $3(1.1 \%)$ \\
\hline Others & $1(0.4 \%)$ & $0(0.0 \%)$ & $1(0.4 \%)$ \\
\hline
\end{tabular}

Note: 34 respondents had multiple responses

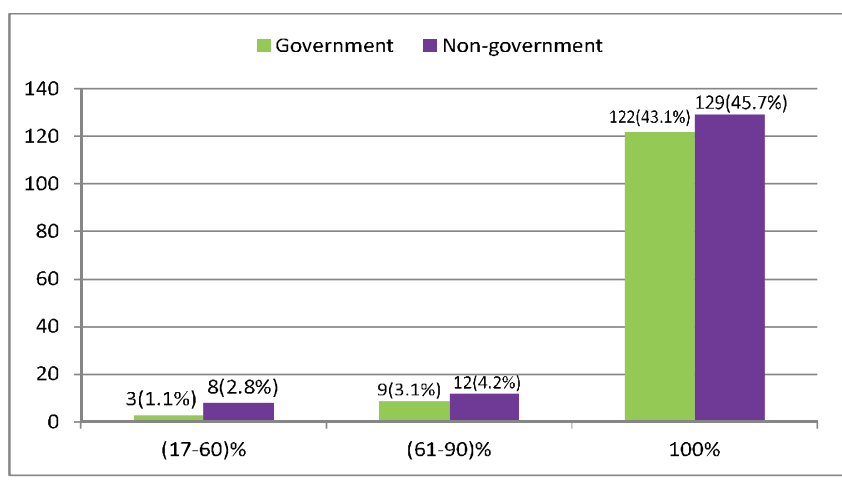

Figure-2: Distribution of respondents by percentage of health care cost shared as out of pocket $(n=283)$

\section{Dscussion}

This descriptive cross-sectional study was undertaken in an attempt to generate some scientific data on awareness and WTP for health insurance in the context of lack of such data in our country perspective. The study was conducted in real working environment of concerned organizations. The extent of awareness found in present study was better than other similar studies like study done in Ethiopia ${ }^{11}$ where more than half (55.2\%) had never heard of the health insurance scheme and the study conducted in Kampala district of $\mathrm{Uganda}^{12}$, where $57.3 \%$ had never heard about health insurance. Another study done in Kinshasa ${ }^{13}$, found that separately only $44.5 \%$ of government employees and $70 \%$ of private sector employees knew about health insurance which was also lower than the result of the present study. Again, that study revealed that government employees were much more ignorant 
about health insurance than their private sector counterparts as only $44.5 \%$ of them knew it against $70 \%$ of private sector. One study conducted in Punjab, India ${ }^{14}$ on common people showed better extent of awareness than that of present study where, $8.7 \%$ were not aware, 19.4\% were aware and subscribed and $71.9 \%$ were aware but did not subscribe for health insurance.

The proportion of employees with willingness to join was found less than the present study in the study conducted in Uganda ${ }^{15}$, where it was 77.5\%; in the study conducted in Ethiopia ${ }^{11}$, that was $71.3 \%$ and in the study conducted in Kampala ${ }^{12}$ that was $41.2 \%$. Among slightly different group of population such as informal workers, willingness to join was found as; in a study done in Tamil Nadu, India ${ }^{16}$ that was 63\%; in another study done in Hanoi, Vietnam ${ }^{17}$ that was $48.4 \%$ and both were lower than that found in present study. Another study conducted in Wuhan, China ${ }^{18}$ found willingness to join among $87.7 \%$ informal workers which was higher than that of present study. Present study revealed that though non-government employees' WTP (Tk 282.4 \pm 194.5 ) is higher than that of government employees (Tk $241.2 \pm 196.5$ ); by percentage of monthly income, the government employees were willing to pay on average more (1.7\%) than that (1\%) of non-government employees.

The WTP revealed by present study (Mean Tk $261.3 \pm 196.3$, approximately USD 3.4) was lower than that found in few other studies. In the study carried out in Zambia ${ }^{19}$, the mean WTP was USD 6.7 per month and as a percentage of monthly salary in the public and private sectors was $5.9 \%$ and $4.6 \%$ respectively. In another study conducted in Uganda ${ }^{15}$, mean WTP of government and private sector formal employees was found USD 11.00 per month. In the study conducted in Wolaita Sodo Town of Ethiopia ${ }^{11}$, the majority of government teachers (47.1\%) expressed their WTP as $4 \%$ or more of their monthly salary. In the study done in Kampala district of Uganda ${ }^{12}$, among government teachers, 38.8\% expressed WTP less than $4 \%$ of salary, $16.3 \%$ expressed WTP 4\% and $12 \%$ expressed WTP more than 4\%. This variation in WTP with present study might be due to difference in health insurance package or due to different level of awareness prevailing in those areas.

In current study, most of the employees (67.8\%) wanted to pay premium monthly. Different results were observed in other studies such as: in the study conducted in Kampala ${ }^{12}$, 39.5\% preferred to pay annually, while only $20 \%$ were willing to contribute monthly; in a study in Pakistan ${ }^{20}, 46 \%$ were in favor of yearly installment and only $15 \%$ monthly. The study done in Kinshasa ${ }^{13}$, exhibited a bit different result than present study regarding OOP expenditure where separately, greater percentage (83.4\%) in the public sector used out-of-pocket financing in comparison to their counterpart (71.2\%) in the private sector.

\section{Conclusion}

Health insurance is a priority issue in the strategic agenda of Bangladesh, as it is the key to achieve Universal Health Coverage (UHC). UHC is one of the major targets set for Sustainable Development Goal (SDG)-3 to be achieved by 2030. While Bangladesh exhibits substantial improvements in different fields towards achievement of SDG, UHC still remains a challenge. Introduction of health insurance, appropriately designed for each population group with the provision of contribution from people, government and employers can ease the access to health care by removing barrier of OOP payment at the point of service. Awareness in this regard at all levels and undertaking appropriate action plan with no loss of time at policy level is imperative for achieving UHC within stipulated time.

\section{References}

1. Ahsan SM, Khalily MAB, Hamid SA, Barua S. The Microinsurance Market in Bangladesh: An Analytical Overview. Bangladesh Development Studies. 2013; 34(1):S54-S63.

2. World Health Organization. Sustainable health financing structures and universal coverage- 64th World Health Assembly Agenda. Geneva: World Health Organization; 2011:13-4.

3 Health Economics Unit. Expanding Social Protection for Health Towards Universal Coverage- Health Care Financing Strategy 2012-2032. Ministry of Health and Family Welfare: Government of Bangladesh; 2012:1-19.

4. Normand C, Weber A. Social Health Insurance: A Guide Book for Planning. Geneva: World Health Organization; 1994: S1:2-3.

5. Bangladesh Bureau of Statistics. Preliminary Report on Economic census 2013. Ministry of Planning: Government of Bangladesh; 2013:17-8.

6. Gertler PJ. On the Road to Social Health Insurance: the Asian Experience. World Development. 1998; 26(4):717-32.

7. Ryan M, Gerard K, Amaya-Amaya M. Discrete Choice Experiments in a Nutshell. In: Bateman IJ. Editor. Using Discrete Choice Experiments to Value Health and Health Care. Vol 11,Netherlands: Dordrecht, Springer Academic Publishers; 2008:256.

8. Zweifel P. Moral Hazard and Consumer Incentives in Health Care.In: Arrow KJ, Intriligator MD. Editors. Handbook of Health Economics. Vol1, Netherlands: Amsterdam, Elsevier Science BV 2000:410-49.

9. Sampietro CL, Phillips VL, Hutchinson AB. Eliciting women's preferences in health care: a review of the literature. International Journal for Technological Assessment in Health Care. 2004; 20(2):145-55.

10. Nanna A. Health Insurance in Developing Countries: Willingness to Pay for Health Insurance in Thailand using Discrete Choice Experiment Methods (Thesis). Perth, Australia: Curtin University; 2011:11-45.

11. Agago TA, Woldie M, Ololo S. Willingness to Join and Pay for the Newly Proposed Social Health Insurance Among Teachers in Wolaita Sodo Town South Ethiopia. Ethiopian Journal of Health Science. 2014; 24(3):95-202. 
12. Byabashaija AA. The knowledge and views of teachers in government educational institutions in Kampala district on the proposed social health insurance scheme in Uganda. Health policy and development. 2009; 7(1):1-9.

13. Kayiba T, Rankhumise EM. Employees' Perceptions Regarding Social Health Insurance: A Case of Kinshasa, Democratic Republic of Congo. African Journal of Business Management. 2011; 5(28):11309-15.

14. Bawa SK, Verma R. Awareness and Willingness to Pay for Health Insurance: An Empirical Study with Reference to Punjab India. International Journal of Humanities and Social Science. 2011; 1(7):100-8.

15. Muheki CW. Willingness to Pay for Social Health Insurance: A Case Study of Kampala, Uganda (Dissertation). Cape Town, South Africa: University of Cape Town; 1998:75-9.

16. Vanithamani G. The Awareness, Enrolment and Willingness to Participate in the Health Insurance Schemes among the Women
Industrial Workers. Shanlax International Journal of Economics. 2013; 1(3):21-9.

17. Huyen DTT, Minh HV. Willingness to Pay for Health Insurance among Informal Sector Workers: A Case Study from Hanoi Capital Vietnam. Vietnam Journal of Public Health. 2014; 2(2):24-31.

18. Barnighausen $T$, Liu $Y$, Zhang $X$ et al. Willingness to pay for social health insurance among informal sector workers in Wuhan, China: A contingent valuation study. BMC Health Serv Res. 2007; 7:114.

19. Kaambwa BC. Willingness to Pay for Social Health Insurance (SHI) in Zambia- A Two Stage Regression Approach (Dissertation).Cape Town, South Africa: University of Cape Town; 2002:52-79.

20. Sarwar A, Qureshi HA. Awareness and Willingness to Buy Private Health Insurance and a Look into its Future Prospects in Pakistan. European Journal of Business and Social Sciences. 2013; 2(1):69-81. 